\author{
Dick Krickus* \\ Mary Washington universitetas
}

\title{
Barack Obama ir saugumas Baltijos jūros rytiniame regione
}

\begin{abstract}
Šis straipsnis aptaria kai kuriuos nuogąstavimus, kurie tvyro Baltijos jūros rytiniame regione ir yra susiję su Vašingtono įsipareigojimu šio regiono šalių saugumui vadovaujant Barackui Obamai. Toks susirūpinimas, rodantis, kad Obamos Baltieji rūmai, matyt, buvo gana nedėmesingi, neturi jokio pagrindo. Pavyzdžiui, naujoji antibalistinè sistema, kurią JAV ketina dislokuoti Europoje, yra pranašesnė nei ta, kurią palaikẻ Busho administracija. Obamos kampanija siekiant atkurti santykius su Rusija pasitarnaus Europai. Ir dar, Obama jau pademonstravo, kad, siekdamas pagerinti JAV įvaizdi pasaulyje švelniomis priemonėmis, jis tuo pat metu ryžtingai rodo kietą kumšti Afganistane, kur Rusija yra paslaugi partnerè. Iš to išplaukia, kad Vidurio ir Rytų Europos šalys turètu paremti JAV sieki atkurti santykius su Rusija, nors sẻkmė nẻra garantuota. Savo ruožtu Rusija privalo atsižvelgti į Baltijos jūros rytinio regiono šalių interesus, jei tikisi produktyvių santykių su Vakarais. Tuo pačiu Europos Sajunga privalo plètoti tokią energetinio saugumo programą, kuri tenkintų ir energiją gaminančiu, ir ją vartojančiu šalių reikmes. Kol kas to nèra. Tikètina, kad tai įvyks Europos Sajungai imantis priemoniu , būtinų reaguojant į ịvairius ekonominius ir politinius iššūkius, keliančius grèsmę Europos Projektui. Vidurio ir Rytų Europos valstybės gali pasikliauti JAV parama, bet tam, kad jokiai priešiškai užsienio jėgai nesuteiktu progos pakenkti savo saugumui, šios šalys privalo spręsti korupcijos problemas savo visuomenėse ir ieškoti sąlyčio tašku, spręsdamos nesutarimus su kaimynèmis.
\end{abstract}

\section{Ivadas}

Po 2008 m. Rusijos-Gruzijos karo, Vidurio ir Rytų Europos šalių vadovai susirūpino dèl išaugusios grèsmès saugumui. Jie atkreipè dèmesị ị tai, kad pirmą kartą po šaltojo karo Rusijos tankai èmė riedèti Europoje Maskvai atplěšus teritoriją iš suverenios valstybès. Buvo reiškiamas nusivylimas, kad galingiausios NATO narès, įskaitant ir Jungtines Valstijas, apibėrè Kremlių griežtais žodžiais, bet ne ryžtingais veiksmais. Nors Gruzija ir nebuvo NATO narè, ji, tarkim, buvo "laukiamajame" ir buvo verta NATO apsaugos. NATO šaltokai reagavus į Rusijos agresiją, Vidurio ir Rytų Europos šalių analitikai klausė, ar, užpuolus jų šalis, būtų taikomas 5-asis straipsnis jų gynybai? ${ }^{1}$

\footnotetext{
* Dr. Dick Krickus - Mary Washington universiteto (Virdžinija, JAV) profesorius emeritas. $2010 \mathrm{~m}$. dèstè Vytauto Didžiojo universitete. Adresas korespondencijai: 10136 Turnberry Place, Oakton, Virginia, USA, tel.+703-938-8140, el. paštas - rvkrickus@aol.com.

'Daug Vakarų komentatorių apeliavo penkių dienų karą kaip ̨̣rodymą kad prasidejo naujas šaltasis karas. Pavyzdžiui, žr. Claire Bigg, "Georgia Woes Could Send Ripple Through Other Frozen Conflict," RFE/RL, August 27, 2008.
} 
Abejonių dèl saugumo daugiausia kilo Baltijos jūros rytiniame regione, kur Estija, Latvija, Lietuva ir Lenkija turi bendras sienas su Rusija. Jie buvo „priešakinėse fronto linijose“ ir dažnai buvo stipriai kritikuojami Kremliaus „griežtojo kurso“ atstovų dẻl savo „antirusiškos politikos“. Karinè doktrina, pateisinanti jègą siekiant apginti rusus, gyvenančius buvusioje sovietinëje erdvëje, kèlẻ nerimą. Tuo pat metu jie skundèsi, kad Rusija, pasinaudodama savo energijos ištekliais, siekia pakenkti jų ekonomikai ir pakirsti demokratiją. Daugeliu atveju šios šalys tapo aukomis kitų priešiškų veiksmu, tokių kaip kibernetinės atakos. ${ }^{2}$ Bet labiausiai jas trikdè tai, kad Rusijos kariniai daliniai rengè puolamuosius karinius mokymus prie jų sienų. Atsakydamos į tai, jos ragino savo Amerikos ir Europos sajungininkus prisiminti Carlo Bildto pastebëjimą, kad geriausias Rusijos ketinimu matas yra tai, kaip ji traktuoja Baltijos šalių demokratijas.

Apmąstant NATO įsipareigojimą Baltijos jūros rytinio regiono šaliu saugumui, didžiausias rūpestis buvo siejamas su Jungtinėmis Valstijomis, kadangi jos yra Aljanso pagrindinè karinè jèga. Su tam tikru nerimu šios šalys stebejjo 2008 metų valdžios perdavimą Vašingtone. Skirtingai nuo kaimynų į vakarus, jos sutiko Baracko Obamos išrinkimą su nuogąstavimu, nes George’o W. Busho prezidentavimo metais santykiai buvo artimi. Jų atstovai taip pat dažnai susitikdavo su Respublikonų partijos veikëjais, kurie padėdavo rengti jų užsienio politikos darbotvarkes. Tarp kitų dalykų šios šalys buvo skatinamos remti Jungtiniu Valstijų vienašališkus užsienio žygius ir tarnauti priešakinėse linijose, NATO siekiant plèstis į rytus. Jos prièmẻ tvirtinimus, kad respublikonai ryžtingesni nei demokratai santykiuose su Kremliumi, nors buvo svariu įrodymu, leidžiančiu abejoti šia nuostata. Tai, pavyzdžiui, naivus Busho tvirtinimas, kad jis pažiūrëjo i Vladimiro Putino sielą ir jam patiko tai, ką pamatė; tai kad jis nesièmé tiesioginiu veiksmų prieš Rusijos invaziją i ̨ruziją; kad nepadejjo šiai ịtrauktai į karą šaliai siekti narystės NATO po to, kai Gruzijos nepriklausomybė atsidūrè pavojuje.

Nepaisant to, Obamą išrinkus prezidentu daug Vidurio ir Rytų Europos šaliu komentatoriu išreiškè susirūpinimą dẻl jo administracijos ịsipareigojimo jų šaliu saugumui. Jie citavo tris savo nuogąstavimu priežastis:

- Obama atsisakė antibalistinès raketu sistemos, kurią Bushas buvo numatęs dislokuoti Rytų Europoje. Jie laikè tai Maskvos pergale ir buvo pasipiktinę, kad Baltieji rūmai net nepasivargino pranešti jiems apie sprendimą, taip stipriai susijusį su ju saugumu.

- Obamos pasižadejjimas atkurti santykius su Rusija ir jo troškimas bendradarbiauti su Kremliumi siekiant pasaulio be branduolinio ginklo buvo įrodymas, kad kita Jalta jau horizonte.

- Obamos pažadas spręsti saugumo problemas ne kieto kumščio, o švelniomis priemonėmis parodè, kad jis nesiryžta panaudoti karinę JAV galią. Tuo silpnas prezidentas padare Amerikos sajungininkus Europoje labiau pažeidžiamus Rusijos spaudimui.

\footnotetext{
${ }^{2}$ Žr. Richard J. Krickus, Iron Troikas: The New Threat From The East, Carlisle, PA: Strategic Studies Institute, U.S. Army War College, March 2006.
} 
Šiame straipsnyje įvertinsime aptariamus tvirtinimus, parodysime, kad jie yra didžia dalimi nepagrịsti ir pateiksime išvadas apie Baltijos jūros rytinio regiono saugumo grėsmes iš Amerikos pozicijų.

\section{Busho atsisakymas priešraketinès gynybos sistemos Rytų Europoje}

2001 m. gruodžio 13 d. prezidentas George’as W. Bushas paskelbė, kad Jungtinès Valstijos pasitraukia iš $1972 \mathrm{~m}$. Antibalistinių raketų sutarties (ABR). Tai galimai parengtų kelią JAV Nacionalinei priešraketinės gynybos sistemai (NRG). Ji susidètų iš trijų daliu - viena būtų Aliaskoje, kita - Kalifornijoje, o trečioji - Rytu Europoje. Paskutiniuoju atveju projektas būtų sudarytas iš radaru sistemos Čekijoje ir priešraketinės sistemos Lenkijoje. Atsakydamas i Maskvos protestus, kad NRG kompromituoja jų branduolinį arsenalą, Bushas nurodè, jog Rytų Europos sistema maža ir nepajègi anuliuoti milžiniškos Rusijos branduolinio smūgio jègos. Ir tikrai, ji buvo suprojektuota tam, kad būtu galima tvarkytis su tokiomis grèsmę keliančiomis šalimis, kaip Šiaurės Korejja ir Iranas, kurios kèlè mažesnę branduolinę grèsmę Jungtinėms Valstijoms ir jų sajungininkèms.

Oficialūs Maskvos asmenys atsisake priimti Busho projekto vertinimą. Jų būgštavimus dèl Prezidento motyvų sustiprino JAV branduolinės pozicijos apžvalga (BPA), išspausdinta $2002 \mathrm{~m}$. Pagal pranešimus spaudoje šis slaptas dokumentas pabrèžè tris tarpusavyje susijusius NRG komponentus: ${ }^{3}$

- JAV branduolinio arsenalo modernizaciją (ir papildymą tikslia ịprastine ginkluote su nedidelio pajègumo branduolinio ginklo naikinamaja geba), galinčią atgrasinti arba užkirsti kelią grèsmę keliančioms šalims ir judejjimams, grasinantiems JAV masinio naikinimo ginklais;

- nacionalinės raketinės gynybos sistemos, kuri kliudytų tokioms grèsmę keliančioms šalims, kaip Iranas ar Šiaurès Korëja, apipilti raketomis Jungtines Valstijas ir jų sajungininkus, įrengimą;

- didelio masto nacionalinio JAV saugumo infrastruktūros atnaujinimą, kad ji taptų veiksmingesne ir našesne jèga.

Busho raketinès iniciatyvos sujungimas su NRG Rusijos pusei suteikè patikimą ịrodymą, kad amerikiečiai siekia igyti pirmojo smūgio gebą. ${ }^{4} \mathrm{Kai}$ kurie Amerikos analitikai palaikè šią niūrią išvadą. Suinteresuotų mokslininkų

\footnotetext{
${ }^{3}$ Žr. Stephen Young and Lisbeth Gronlund, "A Review of the 2002 US Nuclear Posture Review," Union of Concerned Scientists Working Paper, May 14, 2002.

${ }^{4}$ Žr. Pavel Felgenhauer, "Little Room For Compromise over Missile Defense," Washington, DC: Jamestown Foundation, December 11, 2008. Mažiau pesimistinį Rusijos vertinimą dẻl JAV raketu projekto žr. Sergei Rogov, "Obama is Formulating a New American Strategy: A Priority of the US Missile Defense Program will be Development of a Regional Missile Defense System." Nezavisimoye Voyennoye Obozreniye, June 5, 2009.
} 
sajunga (The Union of Concerned Scientists) parengè studiją, kuri pavaizdavo PRG dar labiau provokuojančioje šviesoje. Du amerikiečių analitikai padarè išvadą, kad Jungtinès Valstijos geba suduoti pirmajị smūgi Rusijai, nebijodamos būti nuniokotos atsakomojo antrojo smūgio. ${ }^{5}$

Bushas ignoravo Maskvos skundus, teigdamas, kad sistema negali anuliuoti milžiniškos Rusijos branduolinio smūgio jègos. Dar daugiau, jis pažadejjo suteikti Rusijai detalią informaciją apie ši projektą. Visgi Rusijos analitikai negalëjo nekreipti dėmesio ic svarbu pastebejjimą: JAV viceprezidentas Dickas Cheney's ir gynybos sekretorius Donaldas Rumsfeldas buvo ilgalaikiai ir akivaizdūs NRG šalininkai. Jie niekino ginklų kontrolès iniciatyvas ir savo tikslu laikè JAV karinį dominavimą. ${ }^{6}$ Todèl Rusijos gynybos planuotojai nekantriai laukè ju pasitraukimo iš Amerikos politinès arenos.

Dar būdamas kandidatas i prezidentus, Obama leido suprasti, kad jis turi rimtų abejonių dèl dislokavimo sistemos, kuri neveikia taip, kad susidorotų su grèsme - Irano balistinių raketų arsenalu, kuris dar neegzistuoja. Jau būdamas prezidentas 2009 m. rugsëjo 17 d. jis paskelbè, kad atsisakyta Amerikos raketinio projekto Rytų Europoje dėl naujos sistemos, kuri būtų dislokuota iš pradžiu jūroje, vẻliau ore ir žemëje, ir kurios aiškus tikslas būtų atsakyti į trumpo ir vidutinio nuotolio Irano raketu grèsmę. ${ }^{7}$ Jo pareiškimas sukèlè ugningą kritikos audrą Jungtinėse Valstijose ir Rytų Europoje. Čia, jo kritikai sakè, glūdi įrodymas, kad jis traukiasi spaudžiant Maskvai ir taip elgdamasis kenkia Vidurio ir Rytų Europos šalių, Vašingtono sąjungininkių,saugumui.

Keletas buvusiu Rytų ir Vidurio Europos vadovų, įskaitant Vaclavą Havelą, Lechą Walęsą ir Valdą Adamkų - visi, kurie suvaidino gyvybiškai svarbų vaidmenį jų šalims siekiant nepriklausomybės ir demokratijos - parašè laišką Obamai, abejodami šiuo sprendimu. Būtent, jie išreiškė rimtų abejoniu dèl Vašingtono įsipareigojimo Čekijos, Lenkijos ir Lietuvos saugumui. Šių vadovu požiūriu, Busho projektas tiesiogiai negynè jų šalių nuo „užsienio“ užpuolimo. ${ }^{8}$ Trumpai tariant, Vašingtono priesaika gerbti NATO sutarties 5-ąji straipsni įgautų daug didesnį svorị, jei užpuolimo „iš Rytų“ atveju būtų rizikuojama ir amerikiečių gyvybėmis. Taigi jie suprato Obamos sprendimą kaip pagrindą abejoti jo pasižadejjimu gerbti penktąji straipsnį.

\footnotetext{
${ }^{5}$ Young and Gronlund, op. cit., and Keir Leiber and Daryl Press, "The Rise of U.S. Nuclear Primacy, Foreign Affairs, March/April 2006, pp 42-54.

${ }^{6} \mathrm{Kad}$ suprastume vyrus ir moteris, kurie suvaidins lemiamą vaidmeni George’o W. Busho administracijoje formuojant užsienio politiką, žr. James Mann, Rise Of The Vulcans, New York: Penguin Books, 2004. ${ }^{7}$ Dèl trumpos diskusijos apie Obamos požiūrị i nusiginklavimą ir raketų gynybą žr. Jonathan Alter, The Promise: President Obama, Year One, New York, Simon and Shuster, 2010, pp. 354-55.

${ }^{8}$ RFE/RL, “An Open Letter to the Obama Administration from Central and Eastern Europe,” July 16, 2009.
} 


\section{Santykių su Rusija atkūrimas}

Savo atvirame laiške Obamai oficialūs Rytų Europos valstybių asmenys išreiškẻ susirūpinimą dèl jo plano „atkurti“ santykius su Rusija. „Mūsų viltys, kad santykiai su Rusija pagerès ir kad Maskva pagaliau be išlygu pripažins visišką mūsų suverenitetą ir nepriklausomybę ịstojus į NATO ir ES, neišsipildè. Vietoj to Rusija vèl elgiasi kaip revizionistinè valstybė, XIX amžiaus darbotvarkę vykdanti pagal XXI amžiaus taktiką ir metodus". ${ }^{9}$ Autoriai būgštavo, kad Jungtinès Valstijos ir didžiosios Europos valstybės gali priimti Medvedevo „Galybiu koncerto" planą, pakeisiantị dabar žemyne egzistuojančią, vertybèmis pagrịstą saugumo sistemą. Oficialiuose sluoksniuose, visame Baltijos jūros rytiniame regione, girdëjosi panašių nuogąstavimų. Pavyzdžiui, Lietuvos prezidentė Dalia Grybauskaitè pareiške atsisakiusi susitikti su prezidentu Obama, kadangi ji mananti, jog Obamos diskusijos su Rusija dèl nusiginklavimo „neatitinka Rytu Europos ir Baltijos šalių interesų ${ }^{\prime \prime}{ }^{10} \mathrm{Ji}$ ir kiti regiono vadovai ragino JAV valstybės sekretorę Hillary Clinton apsvarstyti konkrečias operatyvines priemones, kurių JAV galètų imtis siekdama apsaugoti saugumą valstybių, esančiu buvusioje sovietinëje erdvëje.

Lenkai ir baltai nuogąstavo, kad be tokiu priemoniu tam tikru metu jų šalys gali patirti tokị patị Rusijos puolimą, koks teko Gruzijai 2008 metais. Galbūt dar didesnį tiesioginį susirūpinimą kẻlè Maskvos žinojimas, kad jie neapsaugoti, ir tai palengvino Kremliui išplesšti nuolaidu prekybinių reikalu ir diplomatinių santykių atvejais. Vien paramos žodžių neužteko nuraminti jų nuogąstavimams - NATO teko imtis konkrečiu veiksmu, visiškai remiant Vašingtonui, kad pasiektu ši tikslą. Nuoga tiesa buvo tai, kad NATO neturëjo parengto operatyvinio Baltijos jūros rytinio regiono gynybos plano.

\section{Obamos požiūris ị "griežtaji saugumą“ yra švelnus? Jis atsuko Europai nugarą?}

Abejonės dèl Obamos ryžto stokos dorojantis su grėsmėmis „griežtajam saugumui“ dera prie jo oponentų respublikonų sukurptų teiginiu, kad jo, kaip ir jo pirmtakų demokratu, požiūris į nacionalinio saugumo reikalus yra ,"švelnus“. Tuo pat metu Vidurio ir Rytu Europos komentatoriai akcentavo, kad kaip tik respublikonu prezidentas, George’as W. Bushas, atvèré NATO duris lenkams ir baltams, o dabar Obama jas uždaro gruzinams ir ukrainiečiams.

Tuo pat metu Vidurio ir Rytų Europos šalių žiniasklaida citavo Obamos atsisakymą dalyvauti $2010 \mathrm{~m}$. gegužès mèn. ES viršūniu susitikime, kaip tolesni irodymą, kad jo užsienio politikos prioritetuose Europos nebėra. Suprantama,

\footnotetext{
9 Ten pat.

${ }^{10}$ Editor, "Has Grybauskaite helped Lithuania break free from hostage status," The Lithuanian Tribune, September 14, 2010.
} 
kad du karai, kuriuos Amerika kovojo Vidurio Rytuose, reikalavo jo dèmesio, bet jis buvo per daug arogantiškas ignoruodamas pagrịstą susirūpinimą dèl saugumo, kuris daugeliui Europoje vis dar rūpejjo, ypač gyvenantiems buvusioje sovietinejje erdvèje. Jie taip pat pažymèjo, kad, nors ir būdama už ES ribu, JAV turi įtakos Briuselyje ir didžiosiose Europos sostinėse ir ji galètu būti panaudota padèti Vidurio ir Rytų Europos šalims narèms pagrįsti savo susirūpinimą ir paremti savo interesus ES struktūrose santykiuose su Rusija. Labiausiai jie troško bendros ES politikos Rusijos atžvilgiu, politikos, nesusidedančios iš dvišalių susitarimų tarp Berlyno, Paryžiaus ir Romos, iš vienos pusės, ir Maskvos - iš kitos. Jie jautėsi paprasčiausiai palikti nuošalyje nuo sprendimu, stipriai paveikusių ju gerovę.

Drąsinami savo „draugu“" JAV, jie stipriai kritikavo Obamą, kad nesuteikia didesnès pagalbos įtrauktam į karą Gruzijos prezidentui, Michailui Saakašviliui. Pavyzdžiui, kai jis paprašė Vašingtoną aprūpinti jo armiją prieštankine, priešlèktuvine ir kita puolamaja karine ginkluote, jos negavo. Dar daugiau, sekretorei Clinton duodant pasižadejimą remti Gruzijos saugumą, Vašingtonas nesièmè priemonių dèl Gruzijos narystès NATO. Kodèl? Atsakymas buvo akivaizdus: todèl, kad Obama bijojo, jog taip pasielgus jo kampanijai atkurti santykius su Maskva kiltu pavojus - tarp kitų dalykų leistų Kremliui neremti naujosios START sutarties - iniciatyvos, kurią daugelis Rytų Europoje citavo kaip dar vieną įrodymą, kad Obamos Vašingtonas siekia ryšių su Rusija „bet kokia kaina“.

Aukščiau išvardyti pastebejjimai yra pateikti bandant pateisinti būgštavimus, susijusius su Obamos administracijos ryžtu ginti Baltijos jūros rytinị regioną nuo karinių grèsmių „iš Rytų“. Nors šių šalių oficialūs asmenys gali turèti motyvų išreikšti nuogąstavimus dèl Obamos politikos jų kaimynystëje, patys pesimistiškiausi jų rūpesčiai vis dèlto yra nepagrịsti.

\section{Tiesa apie Obamos antibalistinių raketụ sistemą}

Robertas Gatesas - gynybos ministras Busho vyriausybejje - anksčiau pasirašęs raketinės bazès Rytu Europoje statybos dokumentus, paaiškino, kodèl jis pakeitẻ savo požiūrį ir dabar atidavè pirmenybę prezidento Obamos iqvedamai sistemai. Busho sistema buvo suprojektuota atremti Irano tarpžemyninių balistinių raketų (TBR) grèsmei, bet žvalgybos duomenys parodè, kad ši grèsmè tolima. JAV turèjo spręsti dèl artimos grèsmès, susijusios su Irano trumpo ir vidutinio nuotolio raketomis, kurios netrukus turëjo būti parengtos. Dar daugiau, pagal Busho programą, JAV apsauga būtų buvusi užtikrinta tik 2017 metais, bet pagal naujają pirmoji fazè būtų užbaigta jau 2011 metais. Tuo metu ,....mes dislokuosime išbandytas jūroje bazuojamas SM-3 raketu gaudymo sistemas, kurių geba didèja tose srityse, kuriose mes matome didžiausią grèsmę Europai.“ Kaip Gatesas pabrèžè, ši Aegis sistema veikia ir yra pigesnè 
negu Busho projektas|! $\left.\right|^{11}$ Daug Pentagono vadų laikèsi gana panašios pozicijos ir dvejojo, ar išmintinga švaistyti tokias milžiniškas sumas abejotinos vertès sistemai, kai tuo pat metu Amerikos ginkluotosios pajègos pervargusios dèl dviejų karu, kariaujamų Vidurio Rytuose.

O kaip dèl kaltinimo, kad Obama atsisakẻ Busho sistemos spaudžiant Rusijai? Gatesas atsakè, „Rusija visada buvo paranoiška dèl jos (sistemos Rytu Europoje), bet George'as Bushas buvo teisus. Tai nebuvo grèsmè jiems." Ir pridejjo: "Jei viso to netiesioginis rezultatas yra tai, kad rusai jaučiasi mažiau paranoiški ir dabar nori veiksmingiau dirbti su mumis spręsdami tokias grèsmes, kaip Irano balistinès raketos arba branduolinè veikla Irane, tai gauname dividendų. ${ }^{\prime 12}$

Vis dèlto, net tie, kurie pritarè Obamos sprendimui dislokuoti naują raketinès gynybos sistemą, traktavo sprendžiamą problemą pagal tai, kaip ji buvo paskelbta. Pavyzdžiui, laikraštyje Washington Post "op-ed" skiltyje Ann Applebaum, labai gerbiama Amerikoje straipsnių autorè ir Lenkijos užsienio reikalų ministro Radeko Sikorskio žmona, barè administraciją, kad ji atvirai neįspëjo suinteresuotu pusių apie prezidento sprendimą. ${ }^{13}$ Daug oficialių Vidurio ir Rytų Europos asmenų pirmą kartą sužinojo apie tai iš žiniasklaidos, bet ne per diplomatinius kanalus. Tai buvo tipiškas pavyzdys, rodantis, kad nauja, nepatyrusi Amerikos administracija yra neapsaugota nuo klaidu, kuriu daugiau patyrusi administracija būtų išvengusi. Klaida buvo padaryta ne iš pikto, bet, nepaisant to, ji buvo bereikalingas įžeidimas, kurị daug Europos apžvalgininkų traktavo kaip derantị prie Obamos nenoro turèti Europos šaliu lyderius "îtakos grupëje“.

\section{Santykių su Rusija atkūrimas pasitarnauja Europai}

2008 m. birželio mèn. Berlyno kreipimesi Rusijos prezidentas Dmitrijus Medvedevas kvietė pradèti naują saugumo bendradarbiavimo erą tarp Amerikos, Europos ir Rusijos. ${ }^{14}$ Pasak jo, , ,vienpoliškumo momentas “ , kada JAV veikè kaip pasaulio hegemonas, pasibaigè, o visos saugumo institucijos, susijusios su Amerikos pasauliniu dominavimu, įskaitant NATO, jau nebeveikia. Jo žodžiai buvo mandagiai išklausyti, bet nesulaukè konkretaus atsako.

Praëjus dviem mėnesiams, rugpjūčio karas užkirto kelią rimtai ir neemocingai diskusijai, susijusiai su šiuo pasiūlymu. Kritikai klausè: „kaip gali

\footnotetext{
${ }^{11}$ Robert M. Gates, “A Better Missile Defense for Safer Europe,” New York Times, September 20, 2009.

12 Ten pat.

${ }^{13}$ Ann Applebaum, "Letting Europe Drift," Washington Post, September 22, 2009. Dèl naujos sistemos analizės žr. Greg Bruno, "National Missile Defense System: A Status Report," New York: Council on Foreign Relations, March 18, 2009.

${ }^{14}$ Dmitry Medvedev, Berlin Address, June 6, 2008, President's Office, Moscow, Russia. Dèl išsamios diskusijos apie Medvedevo planą žr. Richard J. Krickus, Medvedev‘s Plan: Giving Russia A Voice But Not A Veto In A New European Security System, Strategic Studies Institute, U.S. Army War College, December 2009.
} 
Vakarai toleruoti tokias derybas, kai rusų kariuomenẻ jau įsiveržusi į Gruzijos teritoriją, o Maskva jau atplèšusi ir Abchaziją, ir Pietų Osetiją nuo Gruzijos ir skelbia, kad abu anklavai yra nepriklausomos valstybės." Kiti pažymèjo, kad „vertybių skirtumas“ išstūmė bet kokius „bendrus interesus“, kuriuos turèjo Vakarai ir Rusija. Tačiau netrukus, nors ir neatmetę tokių abejonių, rimtų saugumo derybų su Rusija šalininkai pareiškè, kad Gruzijos karas faktiškai parodè, kokios svarbios yra tokios derybos, siekiant išvengti tolesnio konflikto Europoje. Be to, buvo nerimą keliančiu įrodymų, kad Gruzijos prezidentas Michailas Saakašvilis vykdė provokacinę politiką ir netvarkė reikalų taip, kad pagerintų Gruzijos perspektyvas tapti NATO nare. Netgi jeigu Maskva apgaule privertẻ jauną, sunkiai suvaldomą Gruzijos prezidentą pradèti puolimą prieš Pietų Osetiją, jis pats èmėsi neapgalvotų veiksmų, leidusių tam įvykti. Europos Sajunga atliko tyrimą ir parengè pranešimą, kur buvo leidžiama suprasti, kad kaip tik jis pradèjo karą. Panašius kaltinimus pateikè ir nepriklausomi saugumo analitikai. ${ }^{15}$ Vèliau Amerikos ir Europos vadovai atsuko jam nugara, kad jo neprognozuojamas elgesys nesukeltų dar vieno karinio konflikto su Rusija. ${ }^{16}$

Nors buvo išnagrinèta daugybė priežasčių, sukèlusių penkių dienų karą, nebuvo atkreiptas dėmesys į tai, kad jei George'as W. Bushas nebūtų įsiveržęs į Iraką, vargu ar 2008 metais apskritai būtų įvykęs Gruzijos-Rusijos karas. Rusijos gynybos planuotojai žinojo, kad slegiama karo Irake naštos, kuris pareikalavo daugelio gyvybiu ir milijardų dolerių, ir sugrižus ì Afganistaną Talibanui, Amerikos kariuomenè buvo pernelyg apsunkinta ir nebuvo pasirengusi imtis atsakomujuc kariniu priemonių Europoje. Be to, Busho valdymo laikotarpiu tarptautinė JAV svarba buvo gerokai smukusi ir tuomet mažai Europos vadovu norèjo būti siejami su Vašingtonu. Dar labiau pablogino reikalus tai, kad jau grèsė pražūtingas ekonomikos krachas. Šiomis aplinkybėmis karingai nusiteikę sluoksniai Maskvoje buvo tos nuomonès, kad jie gali veikti be susikompromitavusios Vašingtono vadovybès įsikišimo.

Nors tokios galingos NATO narès Europoje, kaip Prancūzija ir Vokietija, ir toliau žadèjo paramą Gruzijai dèl narystės Aljanse, jos taip pat pažymëjo, jog laikas šiam įvykiui dar neatëjo. Oficialūs Amerikos asmenys skelbẻ panašius pažadus ir aprūpino Tbilisị karine îranga, tačiau atsisakẻ suteikti Gruzijai puolamąją ginkluotę. Tačiau kalbant apie NATO plètrą daugelis Vidurio ir Rytų Europos regione užmiršta, kad būtent demokratas Billas Clintonas èmèsi iniciatyvos paruošti dirvą galimai visų vadinamuju , „naujosios Europos“ šaliu narystei ir šias jo pastangas Kongrese paremė netgi respublikonai.

Praradusi pasitikejjimą Busho administracija, Maskva palankiai reagavo į Obamos išrinkimą, manydama, kad Johno McCaino pergalè įšaldytų Amerikos-Rusijos santykius ir jie būtų tokie, kokie buvo per paskutiniuosius ketverius

${ }^{15}$ Dèl Rusijos veiksmams palankios, o Gruzijai kritinės analizès žr. Mark Almond, "Plucky little Georgia? No, the Cold War Reading Won't Wash: It is Crudely Simplistic to Cast Russia as the Sole Villain in the Clashes over South Ossetia, The West Would Be Wise to Stay out," The Guardian, August 8, 2008. ${ }^{16}$ Žr., pvz. „liberalaus vanago“ nuomonę, Michael O‘Hanlon, "Don't Rush Georgia and Ukraine Into NATO," Washington Times, December 2, 2008. 
Busho kadencijos metus. Tarp kitų dalykų Rusijos komentatoriai pažymëjo, kad vienas iš McCaino užsienio politikos patarëjų Randy’s Scheunemannas buvo apmokamas lobistas Gruzijos vyriausybëje. Kai kas netgi manė, kad McCaino stovykla paragino Saakašvili pradèti provokacinius veiksmus, tikintis, kad konfliktas su Rusija kaip nors padès McCainui siekiant prezidento posto.

2009 metu pavasarị Obama susitiko su Rusijos prezidentu Medvedevu, o vèliau - su ministru pirmininku Putinu ir pažymèjo, jog norètų atkurti santykius su Rusija. Tai atitiko politiką, kurią palaikẻ tokie respublikonų valstybininkai, kaip Henry's Kissingeris ir George'as Shultzas, kurie teigè, jog draugiški santykiai su Rusija yra gyvybiškai svarbūs JAV saugumo siekiams - kovai su pasauliniu terorizmu, branduolinès ginkluotès plitimo stabdymu ir globalinio atšilimo problemų sprendimu. ${ }^{17}$ Neatidèliotinos ir skubios pastangos siekiant atkurti santykius, be abejo, buvo ratifikavimas to, kas buvo pavadinta naujaja START sutartimi.

Pagal 2010 metų JAV nacionalinio saugumo strategiją, kurią pasirašè Obama, siekiama „,sukurti stabilius, tvirtus, įvairiapusiškus santykius su Rusija, kurie remtųsi abipusiais interesais" . ${ }^{18}$ Ryšium su tuo Amerikos ir Rusijos prezidentai parafavo dokumentą, pakeitusį nustojusią galioti START branduolinès ginkluotès mažinimo sutarti, kurią George’as H. W. Bushas ir Michailas Gorbačiovas pasirašè 1991 m. Sekdami kai kurių Obamos politinių oponentų pavyzdžiu, stebėtojai Vidurio ir Rytų Europos regione išreiškẻ nerimą dèl šių iniciatyvų. Jos buvo laikomos neabejotinu įrodymu, jog Obamos administracija pasirengusi nusileisti Kremliui buvusių sovietinio bloko valstybiu ir buvusių SSRS respublikų kaina.

Tokie oficialūs Amerikos asmenys, kaip valstybès sekretorè Hillary Clinton, nuvyko į šį regioną ir mėgino išsklaidyti būgštavimus tų, kurie jautẻ ši susirūpinimą. Ji pareiškè, kad geri santykiai su Rusija faktiškai sustiprins visų buvusių komunistinių Europos šalių saugumą, o ne pakenks jam. Panašiai kalbëjo ir jos kolegos Berlyne, Londone, Paryžiuje ir Romoje. Priešingu atveju, argi baltai ir lenkai jaustųsi saugesni, jeigu JAV ir Rusijos santykiai remtųsi šaltojo karo principais?

Tačiau reikšmingiausią pritarimą JAV-Rusijos santykiams atkurti pareiškė Lenkijos užsienio reikalų ministras Radekas Sikorskis, entuziastingas ponios Margaret Thatcher, ilgą laiką Kremliaus komentatorių laikytos „kietosios linijos“ šalininke, gerbëjas. JAV Senatui ginčijantis dẻl naujosios START privalumų (antai respublikonų senatorius Jon’as Kyl’is pareiškè, kad jis su savo kolegomis neratifikuos šios sutarties, kol nebus sudarytas naujasis kongresas 2011 m. pradžioje), buvęs Amerikos verslo instituto analitikas išspausdino straipsni, sukèlusį sujudimą pasaulio užsienio politikos sluoksniuose. Jis pareiškè, kad naujoji START, Europos priešraketinės gynybos sistema, ir JAV-Rusijos santykių atkūrimas atitinka Lenkijos ir visos Europos interesus. Jis taip pat

\footnotetext{
${ }^{17}$ Henry Kissinger and George Shultz, "Building on Common Ground With Russia," Washington Post, October 8, 2008.

${ }^{18}$ U.S. National Security Strategy, May 2010, The White House, p. 44.
} 
pažymëjo, jog neratifikavus naujosios START kiltų abejonių dėl pasitikëjimo NATO, kartu ir dèl jos įsipareigojimų 5-ajam straipsniui. ${ }^{19}$ Suprantama, prie jo optimistinio požiūrio prisidejjo ir tai, jog buvo laukiama atvykstant Amerikos karių, padėsiančių Lenkijoje įrengti priešlekktuvinès gynybos sistemą Patriot. Vien tas faktas, jog buvo dislokuoti Amerikos daliniai, leido patikèti Obamos administracijos pažadu ginti Baltijos jūros rytinị regioną.

Žinoma, 2009 m. tragiškai žuvus Lenkijos prezidentui Lechui Kaczynskiui ir daugeliui žymių Lenkijos politikų ir kariuomenės vadu, pasauli sužavëjo tai, kas įvyko vèliau: ryškus santykių tarp Varšuvos ir Maskvos pagerëjimas. Ypač verti dėmesio atrodė ministro pirmininko Vladimiro Putino užuojautos žodžiai ir veiksmai. Iš tikruju, šis tragiškas įvykis ir Rusijos reakcija ịjį iš dalies paaiškina, kodẻl Lenkijos vyriausybẻ vẻliau atkūrẻ santykius su Maskva.

Zbigniewas Brzezinskis, žmogus, kurio pavardè neleidžia Kremliaus valdovams šypsotis, prisijunge prie Vakarų analitiku, kritikavusių Putino pabrèžiamą Varšuvos ir Maskvos draugiškumą kaip galimą ryškų santykių tarp šių senu priešininkių atkūrimą. „Nemanau, kad tai Rusijos žaidžiamas žaidimas“, raše jis Time žurnale. „Tai kažkas nuoširdaus ir labai naujo.“ Buvęs prezidento Jimmy Carterio patarëjas nacionalinio saugumo klausimais ir ịtakingas žmogus Obamos administracijoje padare išvada, kad, jei tai rodytų Lenkijos ir Rusijos susitaikyma, "geopolitiniu požiūriu tai prilygtų Vokietijos ir Lenkijos susitaikymo svarbai“ ${ }^{20}$

Nors Baltijos valstybès ir pripažino, jog teigiamai vertina draugiškus santykius su Rusija, tačiau ị santykių atkūrimo iniciatyvą jos žiūrëjo atsargiai, daugiausia dèl to, kad, skirtingai nuo didžiosios kaimynès Lenkijos, sumažèjus jų svarbai jos tapo labiau pažeidžiamos Rusijos spaudimui. Taigi, iki pat svarbaus NATO viršūnių susitikimo Lisabonoje 2010 m. lapkričio viduryje, kai spaudoje mirgèjo antraštės apie naują Aljanso strateginę koncepciją ir suartëjimą su Rusija, estai, latviai ir lietuviai išliko budrūs.

O oficialūs Baltujų rūmų asmenys citavo teigiamus Kremliaus atsiliepimus apie bendradarbiavimą su Vakarais saugumo srityje. Pavyzdžiui, jis pritarė griežtesnėms tarptautinėms priemonėms priversti Teheraną paklusti Jungtiniu Tautų reikalavimams, kad jų atstovui būtų leista apžiūrèti Irano branduolinius kompleksus. Be to, Rusija patvirtino savo ryžtingus žodžius konkrečiais veiksmais, kuomet nutraukė priešlèktuvinių raketų S-300 pardavimą Iranui ir neteko arti vieno milijardo doleriu. Tuo pat metu Rusija leido naudotis savo sausumos ir oro keliais tiekiant aprūpinimą NATO-Amerikos Tarptautinėms saugumo paramos pajėgoms (ISAF) Afganistane. Šiam reikalui anksčiau naudotasi uostais Latvijoje, o nuo 2010 m. gruodžio mèn. Klaipėdos uostas taip pat turètu atlikti panašią funkciją. Rusija apmokè afganų sraigtasparnių pilotus, finansavo vystymo programas, teikė ISAF pajėgoms vertingą žvalgybinę informaciją bei ginkluotę (nors ir ne veltui), kad padètu joms sunaikinti Al-Qaeda teroristus ir sutriuškinti Talibaną, keliantiems grėsmę Hamido Karzajaus vyriausybei bei jo tautos nepriklausomybei.

\footnotetext{
${ }^{19}$ Radek Sikorski, “Time To Ratify New START,” Project Syndicate, November 11, 2010.

${ }^{20}$ Zbigniew Brzezinski, "From Poland's Tragedy, Hope for Better Ties with Russia," Time CNN World, April 19, 2010.
} 


\section{Obama ir NATO valstybių saugumas}

Obamos administracija ne mažiau nei jos pirmtakai palaiko savo sajungininkus Baltijos jūros rytiniame regione. Obama ir toliau laikosi įsipareigojimo visu NATO narių saugumui. 5 straipsnio reikšmę sustiprina tas faktas, kad jis padëjo pagerinti Amerikos įvaizdi tarptautinès bendrijos akyse. Busho valdymo metais jis taip sparčiai prastėjo, kad netgi Europos viešoji nuomonè rodè, jog žmonès baiminasi Amerikos piktnaudžiavimo savo galia labiau nei panašiu veiksmų iš komunistinės Kinijos pusès. Obama, nors ir patyrè sunkumų šalyje ir kai kurių nesėkmių užsienyje, išlaikè sugebẻjimą daryti įtaką užsienio lyderiams taip, kad Bushas toli gražu jam neprilygtų. Be to, Taline JAV valstybės sekretorė Hillary Clinton pažymëjo, kad JAV pažadas ginti Europą panaudojant ten dislokuotą JAV branduolinę ginkluotę bus vykdomas netgi ratifikavus naujają START sutarti, o Vašingtonas atkreips dèmesį į Europos susirūpinimą dèl didžiulio Rusijos taktinių branduolinių ginklų arsenalo.

Apskritai paėmus, tvirtinimai-kaip ir požymiai-kadJAV nebeskiria tinkamo dèmesio Europai, turi būti vertinami pasitelkiant kai kuriuos tikrovès faktus.

Pirmiausia, Obama gavo užnuodytą Busho palikimą. Kaip pažymëjo daugelis analitiku, tarp kuriu tokie respublikonu politikai, kaip generolas Brentas Scowcroftas ir James’as Bakeris (atitinkamai Busho vyresniojo patarèjas nacionalinio saugumo klausimais ir jo valstybès sekretorius), neteisingam karui Irake nèra pateisinimo. Sadamas Huseinas neturejjo pakankamai masinio naikinimo ginklu, ypač branduoliniu, kad keltu grèsmę JAV, ir nebuvo susijęs su Al-Qaeda. Bet Obama paveldejo ne tik tą bẻdą, bet ir "teisingą karą" Afganistane, ỉ kuri daugelị metu jaunesnysis Bushas nekreipé dèmesio, tuo palengvindamas Talibanui atsigauti.

Pažymėtina, kad Obama nesudvejojo ir dislokavo dar 30000 JAV karių kovai Afganistane; jam vadovaujant, JAV specialiosios pajègos parodė ypatingą drąsą, nukaudamos įtakingus Talibano ir Al-Qaeda veikejjus ir, nepaisydamas Pakistano protestu, Obama įsakè smarkiai padidinti nepilotuojamujų lèktuvu atakų skaičiu prieš Pakistano teroristus, naudojančius šią šalį kaip bazę rengti atakoms prieš NATO ir JAV kariuomenę Afganistane.

Antra, pasaulio galios centrui pasislinkus iš Vakarų i Rytus, Obama turëjo atsižvelgti į tai, jog atsirado naujų pasaulio žaidèjų, esančių už Europos ribu, tokių kaip Brazilija, Kinija ir Indija -vadinamosios BRIC valstybės.

Trečia, iš Busho Obama paveldejo ekonomikos nuosmukị, kuris neleido jam nuosekliai ir apgalvotai sudaryti savo globalinę dienotvarkę. Vietoj to reikẻjo îveikti viena po kitos besirandančias krizes, o amerikiečiai priekaištavo, kad jis neatkuriąs JAV ekonomikos. Taip pat reikia prisiminti tai, kad 2010 metu kongreso rinkimuose Amerikos elektoratas ir kandidatai ignoravo užsienio politiką, nors ju šalis kariavo dviejuose karuose.

Ir, pagaliau, savo rinkimu kampanijoje Obamos politiniai konkurentai laikėsi obstrukcionistinės politinės pozicijos, kuri trukdè jam ryžtingai spręsti rimtas vidaus ir užsienio problemas. 


\section{Apibendrinimas}

Spaudos konferencijoje, įvykusioje po NATO viršūniu susitikimo Lisabonoje, keleto Vidurio ir Rytu Europos vyriausybių narių išreiškẻ pritarimą Vašingtono siekiams atkurti santykius su Rusija:

- Latvijos užsienio reikalų ministras Valdis Kristovskis pareiške, kad jis palaiko naujosios START sutarties ratifikavimą JAV Kongrese ir pridūrè: „Mes labai palaikome... šią prezidento Obamos politiką, kuri labai svarbi mūsų regionui."

- Nikolay Mladenov, Bulgarijos užsienio reikalų ministras, pasakè, kad ,....mes visiškai palaikome START sutarties ratifikavimą“. ${ }^{21}$

- Lietuvos užsienio reikalų ministras Audronius Ažubalis taip pat pritarė šiai sutarčiai.

- Lietuvos prezidentė Dalia Grybauskaite, Lisabonoje susitikusi su prezidentu Obama, pasakė: „5-asis straipsnis pagaliau tapo realiai pritaikomas Baltijos valstybėms. Mes turime viską, ko prašème viršūniu susitikime. Turime saugumo garantijas Lietuvai ir atvirų duru politiką NATO, kas reiškia, jog visos demokratiškos šalys galès prisijungti, jei jos laikysis nustatytų reikalavimų. ${ }^{22}$

Prieš šį viršūnių susitikimą oficialūs Amerikos asmenys nenoromis komentavo saugumo garantijas, kadangi, kaip pareiške vienas JAV diplomatas besidominčiam analitikui, „,nèra protinga taip elgtis“. ${ }^{23}$ Tačiau lapkričio mèn. lenkų laikraštis Gazeta Wyborcza pranešè, kad NATO turi planą ginti Baltijos jūros rytinio regiono šalis. Planai Lenkijai, kurie buvo sudaryti 1999 metais, buvo atnaujinti, o naujieji, skirti trims Baltijos šalims, buvo svarstomi. Atsakomybẻ už operacijas buvo numatyta NATO Jungtiniu pajėgų vadovybei Olandijos mieste Brunssume. Užpuolimo atveju būtų dislokuotos 9 divizijos ginti regionui. Be keturių Lenkijos diviziju, JAV, Jungtinè Karalystė ir Vokietija atsiųstų savo pajėgas. JAV ir Britanijos karo laivai taip pat buvo įvardyti kaip vykdymo pajègų dalis, o jiems aptarnauti buvo numatyta keletas Baltijos jūros rytinio regiono uostų. Oro pajègu vienetai, įeinantys ị jau veikiančią Baltijos oro erdvès policijos sistemą, užtikrintų apsaugą kartu su kitais oro pajègų daliniais. ${ }^{24}$

Neseniai pasirodžiusiuose dokumentuose, kuriuos išplatino WikiLeaks, atskleidžiama, kad sausio mèn. NATO sutiko išplėsti Lenkijai sudarytus specialiuosius gynybos planus, įtraukiant ị juos ir Baltijos šalis. Šie dokumentai patvirtino ankstesnius pranešimus, kad toks susitarimas buvo rengiamas. ${ }^{25}$

\footnotetext{
21 "European Foreign Ministers in Support of New START Treaty," 20 November, 2010, America,gov.

${ }^{22}$ Editor, "NATO's cooperation with Russia will be beneficial for Lithuania too," The Lithuanian Tribune, November 21, 2010.

${ }^{23}$ Neoficialus pokalbis su Amerikos diplomatu šiame regione, $2010 \mathrm{~m}$. rugsèjo mèn.

${ }^{24}$ Editor, "Nine possible divisions for defense of Baltic States and Poland," The Lithuanian Tribune,

November 18, 2010.

25 “The US embassy cables: The documents', Guardian.co.uk, December 6, 2010.
} 
Amerikos analitiku, atidžiai stebinčių įvykius Baltijos jūros rytiniame regione, požiūriu, reikètų padaryti keletą išvadų:

- Sekdamos Lenkijos pavyzdžiu, Baltijos šalys turètų prisijungti prie pagrindinių Vakarų valstybių bendradarbiavimo su Rusija kampanijos ir kartu spręsti bendras saugumo problemas Europoje. Ir tam reikia ne steigti naują "galių koncertą" Europoje, o laipsniškai igyvendinti procesą, kur pasiektas susitarimas „lengvesnèse“ srityse pasitarnautu kaip pasitikèjimo stiprinimo priemonè ir kalbant jau apie sudètingesnius tikslus. Iš esmès šiam procesui buvo pritarta NATO viršūnių susitikime Lisabonoje 2010 metų lapkričio mèn. Galima daryti išvadą, kad naujosios START sutarties ratifikavimas reiškia santykių su Rusija atkūrimo kampanijos pergalę, tačiau nėra garantijos, kad ji pagaliau paskatins ilgalaiki bendradarbiavimą tarp Vakarų ir Rusijos saugumo srityje.

- Nuo šiol Europos Sajunga vaidins svarbesnį vaidmeni, užtikrindama saugumą Baltijos jūros rytiniame regione, nei buvo praeityje, kai NATO buvo vienintelis saugumo garantas. Tačiau, kaip pastebejo Dmitrijus Treninas, Rusija turi dèti pastangu, siekdama išspręsti savo nesutarimus ir su Baltijos šalimis, ir su Lenkija. Iš tikruju, tai susiję su svarbesne problema: produktyvūs Europos Sąungos ir Rusijos santykiai nebus įmanomi, kol nebus panaikinta įtampa tarp baltų ir rusuc. ${ }^{26}$ Amerikos baltuc bendruomenè nèra nei gausi, nei turtinga, tačiau turi dideli palaikymą abiejose partijose, o tai kartais leidžia jai pasiekti didesnių tikslų. Tai liudija, pavyzdžiui, spaudos konferencija, kurioje Vidurio ir Rytų Europos vadovai išreiškè savo paramą naujajai START. Kaip atskleide Washington Post, respublikonų senatorius George’as V. Voinovichius (kuris pareiškẻ apie savo atsistatydinimą) tikriausiai bus paraginęs Obamos Baltuosius rūmus organizuoti ši renginį. Ohajo senatorius leido suprasti, kad nors jis ir remia naujają START sutarti, bet nepasirašys jos tol, kol nebus tikras, jog jos patvirtinimas nepakenks Baltijos valstybėms ir jos kaimynems Rytų Europoje. Voinovichius dažnai lankydavosi Lietuvos ambasadoje Vašingtone, tuo parodydamas, kad remia jos saugumą. ${ }^{27}$

- Neatrodo, jog būtų įmanoma atkurti santykius tarp Rusijos ir Baltijos jūros rytinio regiono valstybiu, kol Maskva naudoja savo energijos išteklius rytinėms kaimynėms spausti. Kaip rašè Keithas Smithas, buvęs JAV ambasadorius Lietuvoje, "panaudojusiai "skaldyk ir valdyk" taktiką Maskvai sėkmingai pavyko sutrukdyti vystyti glaudesnį bendradarbiavimą tarp Europos valstybių tiek ekonomikos, tiek saugumo srityse. "28 Visos Vidurio ir Rytų Europos valstybės tebėra pažeidžiamos

\footnotetext{
${ }^{26}$ Dmitri Trenin, "Russia and Poland: friendship that must not fail," Opendemocracy.net, December 2, 2010.

${ }^{27}$ Mary Beth Sheridan, “Arms treaty's approval is another White House save," The Washington Post, December 23, 2010.

${ }^{28}$ Keith C. Smith, "Russian Energy Dependency and the Conflicting Interests of Old and New Europe," Center for Strategic and International Studies, May 12, 2010, p. 2.
} 
energetinio šantažo, turint galvoje jų priklausomybę nuo Rusijos energijos išteklių eksporto. Europos Sajungai nepavyko imtis šios problemos sprendimo.

- Kad būtų ištaisyta ši klaida, Smithas ragina Europos Sajungą plètoti bendrą energetikos politiką, kuri paisytų ir energiją tiekiančių, ir energiją vartojančių valstybių interesų. Tačiau turint omenyje tą faktą, kad didžiosios Europos šalys, kaip, pavyzdžiui, Vokietija, teikia pirmenybę dvišaliam, o ne Europos Sajungos požiūriui ị Europos priklausomybę nuo Rusijos energijos ištekliu tiekimo, būtų neprotinga manyti, kad dabartinès tendencijos veda šia kryptimi. Iš tikro, Europos ekonomikos bẻdos ir būgštavimai dẻl euro gyvybingumo suteikẻ peno euroskeptikams ir kitoms interesų grupėms, keliantiems rimtą grėsmę visam Europos projektui. Nors kai kurie atkaklūs Europos Sajungos rèmėjai turi vilčiu, kad Europos ekonomikos problemos suteiks naują stimulą kurti suvienytą Europą su stipria vykdomaja valdžia - tai būtina sąlyga produktyviems santykiams su Rusija - tačiau atrodo, jog turimi faktai rodo ne tokią perspektyvią Europos Sajungos ateitį. Tai reiškia, jog, padedamos savo draugiškų Šiaurès kaimyniu, Baltijos jūros rytinio regiono šalys turi stengtis per trumpą laiką pasiekti energetinį saugumą. Reikia tikètis, kad ilgainiui Vokietija, kaip ir kitos didžiosios Europos valstybès, supras, kad išmintinga sukurti tokią energetinio saugumo sistemą, kuri Europos Sajungoje skatintų vieningumą, o ne susiskaldymą.

- Korupcija, o ne puolantys rusų tankai kelia didžiausią pavojų saugumui Baltijos jūros rytinio regiono šalims. Korupcinè veikla, pasireiškianti tarp teisèju, teisésaugos ir kitų valdžios pareigūnu, taip pat gydytoju bei pedagogu, daro didelę ir žalingą įtaką regiono visuomenei, kuri yra daug nuveikusi, kurdama demokratinį valdymą bei laisvosios rinkos ekonomiką. Išplitusi korupcija kelia pavojų ekonomikos raidai: užkerta kelią užsienio investicijoms, kenkia prekybiniams santykiams ir didina ekonominę nelygybę. Be to, piktnaudžiavimas valdžia sudaro sąlygas atsirasti politiniam susvetimejjimui, kuris savo ruožtu skatina demagoginę politiką. Esant tokioms sąlygoms, valstybės negali susitelkti ir pasiekti vienybės, kuri reikalinga siekiant nugalèti išorines grẻsmes savo saugumui. Nèra abejonès, kad šalies susiskaldymas skatina priešišku užsienio jẻgu provokacinius veiksmus.

- Tai, kad nèra vieningumo tarp Baltijos jūros rytinio regiono šaliu, ir toliau neleidžia joms kolektyviai spręsti problemu, susijusių su bendrais pavojais jų saugumui. Pavyzdžiui, Lenkijos-Lietuvos santykiai pastaruoju metu pasižymi griežta retorika ir nesugebejimu užbaigti daugybès ginču, skatinančių nesantaiką tarp abiejų tautų. Būtina, kad Lenkija ir jos mažesnès Baltijos kaimynės savo nesutarimus spręstų pačios, o ne Europos Sajunga ar JAV.

2010 m. gruodis 